\title{
INTEGRATING SUNDANESE ETHNOMATHEMATICS INTO MATHEMATICS CURRICULUM AND TEACHING: A SYSTEMATIC REVIEW FROM 2013 TO 2020
}

\author{
Dindin Abdul Muiz Lidinillah ${ }^{1 *}$, Rahman ${ }^{1}$, Wahyudin ${ }^{1}$, Sani Aryanto ${ }^{1,2}$ \\ ${ }^{1}$ Universitas Pendidikan Indonesia, Indonesia \\ ${ }^{2}$ Universitas Bhayangkara Jakarta Raya, Indonesia
}

\section{Article Info \\ Article history: \\ Received Jan 20, 2021 \\ Revised Aug 1, 2021 \\ Accepted Aug 8, 2021}

\section{Keywords:}

Curriculum,

Ethnomathematics,

Sundanese,

Systematic Review

\begin{abstract}
As a country with the most ethnic, cultural, and linguistic backgrounds globally, Indonesia has great potential for the development of ethnomathematics studies. Among those ethnic groups, Sundanese ethnic group and culture is the second-largest after the Javanese ethnic group and culture, making it interesting to study because it has rich cultural elements that can be integrated into the mathematics curriculum in schools. This article explores the development of research on ethnomathematics based on Sundanese culture, including those which are based on the study's scope, the integration of Sundanese ethnomathematics into the school curriculum, and mathematics learning. Based on the investigation, there has been no systematic literature review on Sundanese ethnomatematics. The research was conducted using the Systematic Literature Review method with the PRISMA protocol. The results showed that there were various kinds of research on Sundanese ethnomathematics. There were various kinds of study on Sundanese ethnomathematics integration into mathematics curriculum and teaching using five model categories. The results also showed that RME, CTL and PBL were the most widely used teaching approaches for learning Sundanese ethnomathematics. However, most Sundanese ethnomathematics teaching uses a special approach that varies, developing teaching material, teaching media, and using the context of traditional games.
\end{abstract}

This is an open access article under the CC BY-SA license.

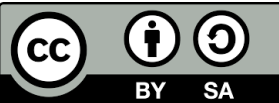

\section{Corresponding Author:}

Dindin Abdul Muiz Lidinillah,

Departement of Mathematics Education,

Graduate School of the Universitas Pendidikan Indonesia

Jl. Dr. Setiabudi No.229, Bandung City, West Java 40154, Indonesia

Email: dindin_a_muiz@upi.edu

\section{How to Cite:}

Lidinillah, D. A. M., Rahman, R., Wahyudin, W., \& Aryanto, S. (2022). Integrating sundanese ethnomathematics into mathematics curriculum and teaching: A systematic review from 2013 to 2020. Infinity, 11(1), 33-54.

\section{INTRODUCTION}

Research on ethnomathematics has developed rapidly since Ubiratan D'Ambrosio delivered his opening speech in 1984 at the Fifth International Congress on Mathematics Education in Adelaide, Australia, on the relationship between mathematics, culture and 
society (Rosa \& Orey, 2016). D'Ambrosio (1985) has provided a foundation for the study of ethnomatematics and its relationship to history and pedagogy. Meanwhile Borba (1990) places ethnomathematics as an epistemological approach to mathematics and presents the basis for studying the relationship between ethnomathematics and education. Since 1984, six international conferences on ethnomathematics (ICEM) have been held every four years, attended by representatives of more than 20 countries (Rosa \& Orey, 2016) and most recently held in Colombia in 2018. This shows that the study of ethnomatematics has so far developed into an interesting field for research.

Ethnomathematics was defined as an anthropological study of mathematical thinking and practice about the relationship between mathematics and culture (D'Ambrosio, 1985; Eglash, 2000) and mathematical modeling, which can help students translate various mathematical ideas and practices found from a cultural element (Rosa \& Orey, 2016). Ethnomathematics is a human creation that directs attention to the cultural roots and social history of mathematics, expressed in the language code of certain sociocultural groups (Cimen, 2014). Ethnomathematics is practiced by cultural groups, including not only indigenous peoples, but also groups of workers, professional classes, and children from specific age groups (D'Ambrosio, 1985). Therefore, ethnomathematics is closely related to the mathematical way of thinking of a society that is related to its culture, and can be integrated in the school curriculum.

Ethnomathematics is a field of research that includes the process of transmitting, disseminating, and institutionalizing mathematical knowledge (ideas, processes, and practices) that originates from the diversity of cultural contexts in history (Rosa \& Orey, 2016). The International Study Group on Ethnomathematics (ISGE) identifies four areas of general interest in ethnomathematics: (a) field research to collect data on mathematics in culture; (b) mathematical work in cross-cultural situations; (c) the application of ethnomathematics in the classroom; and (d) theoretical, sociological, and ethnomathematics policy studies (Rosa \& Shirley, 2016). Meanwhile, There are six essential dimensions of ethnomathematics: cognitive, conceptual, educational, epistemological, historical, and political, that can be used to analyze the socio-cultural roots of mathematics (Rosa \& Orey, 2016). Both the areas of general interest and the essential dimensions of ethnomathematics provide consideration in choosing a research focus on ethnomathematics even though they present different areas of study which are substantially the same.

The ethnomathematics theoretical framework was regarding how to create a more culturally responsive mathematics classroom (Brandt \& Chernoff, 2015; Maksimova, 1967). Teachers must design mathematics teaching based on a diversity of practices that are placed historically, culturally, socially, and politically like other human activities (Gay, 2000; Nam et al., 2018). A pedagogical approach based on ethnomathematical studies can develop mathematics teaching based on student perspectives (Ricardo \& Mafra, 2020) or mathematics teaching that considers the daily mathematics practices of culturally diverse students (François, 2010) to make meaningful relationships and deepen their understanding of mathematics (D'Ambrosio, 2001). This framework can be an ethnomatematic based learning approach in schools.

There are five ethnomathematics curriculum models that integrate aspects of student culture into a holistic learning environment: mathematical epistemology, its content, classroom culture, and mathematics teaching approaches (Rowlands \& Carson, 2002), namely: (a) presenting ethnomathematics as a context which is meaningful for the development of thinking skills; (b) presenting ethnomathematics as a specific cultural content distinct from universal mathematical concepts; (c) as a stage in the development of mathematical thinking that the child goes through; (d) creating a classroom containing a 
cultural context in the form of values, beliefs and learning theory; and (e) presenting mathematical concepts and practices derived from the culture of students.

Teaching mathematics relevant to culture and personal experiences help students know more about reality, culture, society, environmental problems, and themselves (Orey \& Rosa, 2006) Ethnomathematics provides enrichment and new topics that students have never seen before that can be found in cultural practices worldwide (Rosa \& Shirley, 2016). The arguments for using ethnomathematical examples in the classroom are (a) to show students that their own culture contributes to mathematical thinking and (b) to show students different cultures from around the world to build respect for others and contribute to global education (Rosa \& Shirley, 2016). This perspective emphasizes students to have respect for a variety of cultural backgrounds in addition to developing mathematical thinking with cultural contexts.Although ethnomatematics has developed since 1984 to cover various areas and dimensions of research, research on ethnomatematics in Indonesia began in 2011 based on tracing results in the Indonesian journal portal, namely http://garuda.ristekbrin.go.id and the Indonesian repository portal http://rama.ristekbrin.go.id. Several scientific articles published in international journals and proceedings were published after that year.

The study of culture-based education in the Indonesian context is fascinating to conduct. It is because based on the 2010 Indonesian Central Statistics Agency census results (Na'im \& Syaputra, 2010), there are 1340 ethnic groups in Indonesia, which are grouped into 31 clusters of ethnic groups. The Javanese dominate and rank first, which is around $40,22 \%$ of the total population, followed by the Sundanese of around $15,5 \%$, and the third and fourth ranks are the Batak $(3,58 \%)$ and Sulawesi ethnic groups $(3,22 \%)$. Moreover, based on the mapping and verification results, there are 652 local languages in Indonesia. This number does not include dialects and sub-dialects This data illustrates the challenges of studying ethnomathematics in Indonesia, which has a high diversity of cultures and ethnicities.

The diversity of Indonesian cultures inspires research activities on ethnomathematics in every ethnicity and culture in Indonesia. As the second largest ethnic group in Indonesia, research on Sundanese culture from the perspective of ethnomathematics is very interesting to do, as well as research on other diverse ethnic cultures in Indonesia, especially Javanese ethnomathematics as the largest ethnic group.It should be known that many ethnomathematics studies have been carried out involving other ethnic groups and cultures in Indonesia, which gives color to Indonesia's ethnomathematics diversity. Mathematics has existed since the time of the Sundanese people's ancestors and is still part of daily life, especially in rural communities. The challenge is how teachers in schools can integrate ethnomathematics into mathematics teaching that is more dynamic and exciting, fun, and easier to learn (Abdullah, 2017).

Sundanese ethnomathematics based teaching as a curriculum unit can be developed based on five ethnomathematics curriculum models (Rowlands \& Carson, 2002). The development of learning units that are based on an ethnomathematics curriculum can refer to an ethnomathematics based teaching approach framework (Adam, 2004) (see Figure 1). 


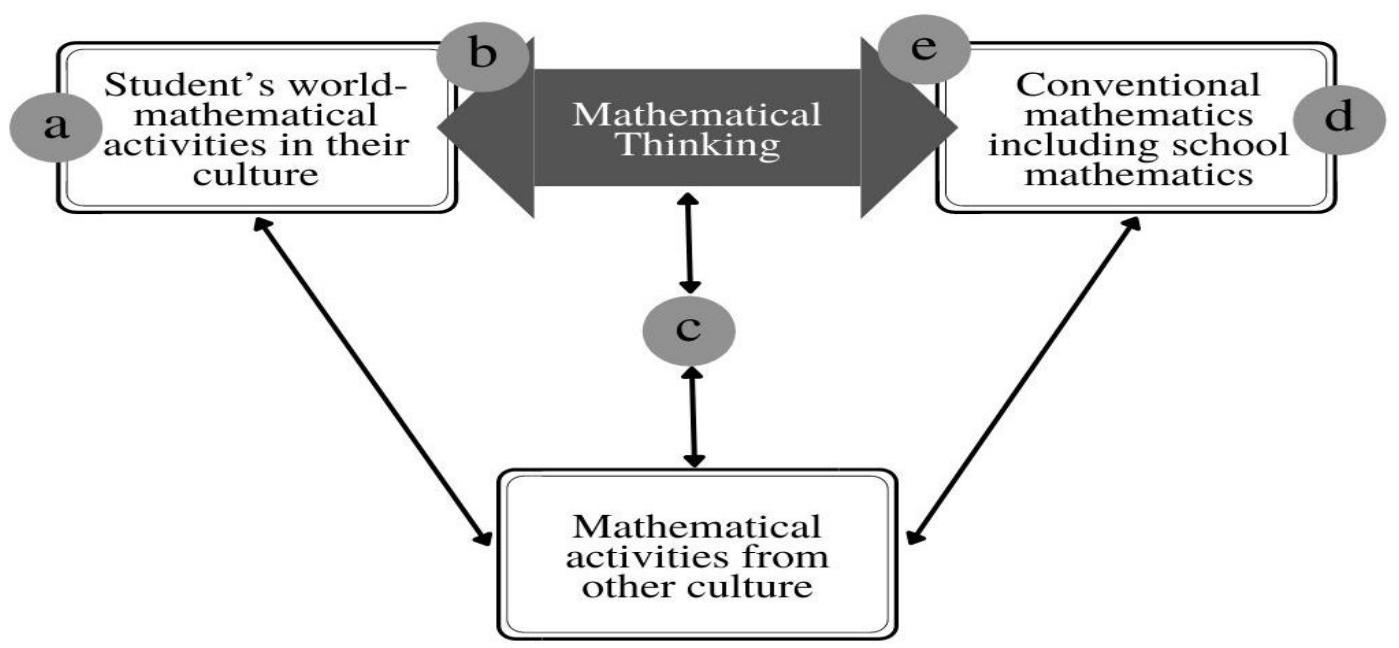

Figure 1. The framework for the ethnomathematics curriculum unit (Adam, 2004)

This model (see Figure 1) can be developed as a learning phase that enables students (Adam, 2004): (a) to become aware of the mathematical activities that exist in their culture; (b) to understand and experience these cultural activities from a mathematical perspective; (c) to relate their mathematical knowledge to other experiences or cultures that use mathematical thinking; (d) to study the use of mathematical systems, notations, and techniques in response to human needs; and (e) to understand conventional mathematics better so as to contribute to understanding the principles of culture-based mathematics. Ethnomathematics curriculum models and ethnomathematics based teaching approach framework are used as frameworks for analyzing the model of integration of ethnomathematics into the school curriculum and ethonomathematics-based learning syntax contained in articles and scientific papers on Sundanese ethnomathematics.

This study is expected to provide a reference as a preliminary study describing the framework and projection of Sundanese ethnomathematics studies which are specifically related to how to integrate Sundanese ethnomathematics into the curriculum and teaching mathematics and what mathematics learning goals can be developed with sundanese ethnomathematics based teaching. To explore more deeply about how ethnomathematics has been carried out in various studies, especially those related to how Sundanese ethnomathematics is integrated into the mathematics curriculum and teaching in schools, the following are the questions raised in this research which uses a systematic review method. The third research question related to the objectives of learning mathematics completes the framework for integrating ethnomathematics into the school curriculum that refers to the standards developed by Joyner and Reys (2000) and National Reasearch Council (Kilpatrick, 2001), a) What are the models for integrating Sundanese ethnomathematics into the school mathematics curriculum? b) What are the approaches to teaching mathematics based on Sundanese ethnomathematics? c) What are the objectives of learning mathematics with a Sundanese ethnomathematics approach?

\section{METHOD}

Researchers used a Systematic Review with the PRISMA Protocol (Preferred Reporting Items for Systematic Review and Meta-Analysis Protocol). The role of the PRISMA Protocol is a procedure for examining and selecting all appropriate empirical 
evidence used to answer the identified research questions. The empirical evidence referred to in this case is scientific research results in the form of journal articles, seminar proceedings and research reports. This method minimizes bias and provides guidelines and a structure for reporting. The PRISMA Protocol consists of 27 checklist items and a four-phase flow chart. The PRISMA Protocol is an evidence-based approach to accurately and reliably report findings from articles for Systematic Review (Moher et al., 2009).

The focus of scoring articles for this systematic review was based on items from the checklist, including title, author, year, research question, cultural setting, method, sample/subject, and findings. Items were selected primarily those of relevance to the research questions and supported additional analysis. The target documents that were traced were journal articles (local, international) and Scopus-indexed proceedings, undergraduate theses, master theses, dissertations. The search was mainly focused on journal portals and repository portals in Indonesia (http://garuda.ristekbrin.go.id and http://rama.ristekbrin.go.id). Subsequently, document searches were carried out on Google Scholar and the Publish and Perish app to find articles that did not appear on both search portals. Several international journal articles and Scopus-indexed proceedings were obtained. The keywords used to search for articles on the Garuda Protal A portal are ethnomathematics, "etnomatematika", "ethnomatematics", and mathematics with culture, local and traditional. Meanwhile, searches in international journals and proceedings used the keywords ethnomathematics and Indonesia.The following is a detailed description of the stages of selecting study sources, namely: (a) identifying journal articles and student research results in the form of undergraduate theses, master theses, dissertations; (b) multiple document screening assisted by Mendeley; (c) removing incomplete documents or obtaining disclaimer notes; (d) selecting documents relevant to Sundanese ethnomathematics studies; (e) checking the quality of documents relevant to the research question; (f) recapping the relevant documents for the next analysis needs.

Descriptive statistics were used to present the data extracted and tabulated. The findings related to the research questions were then presented in the narrative summary. The following is the sample selection process flowchart as a source of the article review in accordance with the PRISMA Protocol for Systematic Review (see Figure 2). 


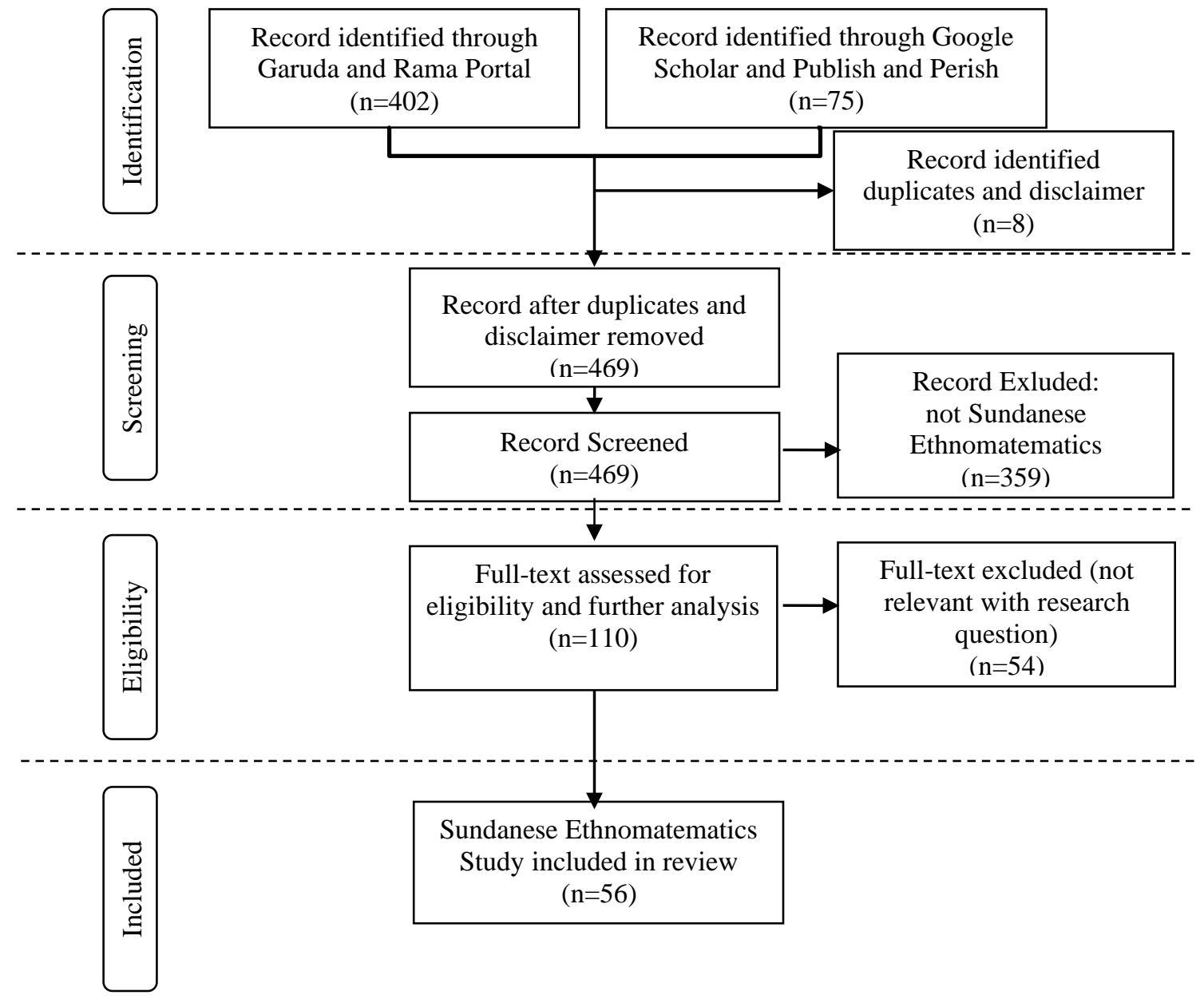

Figure 2. PRISMA protocol flowchart

To demonstrate the document selection process in detail, the following is the number of sources generated through the selection process at each stage of PRISMA.

Table 1. Selection of documents for research

\begin{tabular}{llcccc}
\hline \multirow{2}{*}{ Types of Document } & \multirow{2}{*}{ Search Engine } & \multicolumn{4}{c}{ Number of documents } \\
\cline { 3 - 6 } & Gdentification & Screening & Eligibility & Included \\
\hline Local Journals & Garuda & 311 & 311 & 47 & 29 \\
International Journals & Publish \& Perish & 13 & 13 & 7 & 5 \\
Scopus-Proceedings & Publish \& Perish & 62 & 62 & 14 & 7 \\
Undergraduate Theses & Rama & 74 & 66 & 38 & 14 \\
Master Theses & Rama & 13 & 13 & 2 & 0 \\
Dissertations & Rama & 4 & 4 & 2 & 1 \\
\hline \multicolumn{2}{l}{ Total } & 477 & 469 & 110 & 56 \\
\hline
\end{tabular}

Source documents obtained before the final selection stage described the scope of the Sundanese ethnomathematics study obtained from these source documents. Then, specifically, the presentation and discussion of data were focused on research questions. 
Table 1 show that the identification stage, 477 articles and scientific papers were collected during the initial search stage using the keywords used. These collected documents still contain duplicate documents and ethnomatematic studies throughout Indonesia. Ethnomathematic identification of Sundanese is not enough to be obtained from the title of the article but must be learned from the abstract and the entire document content. After the screening (screening stage) of multiple and incomplete documents, a total of 469 documents remained. Then carried out an examination of the documents to choose which ones contained the Sundanese ethnomathematic study, which then obtained 110 eligible documents (eligibility stage). Then, these 110 documents are presented in a table based on items: title, author, year, research question, cultural setting, method, sample / subject, and findings to be used in the next analysis stage. After that the documents were separated between studies on the relationship of mathematics and culture (54 documents) and studies on the integration of ethnomatematics into the curriculum and teaching (56 documents). These 56 documents are documents analyzed to answer research questions.

\section{RESULTS AND DISCUSSION}

The Sundanese ethnomathematics study referred to here is ethnomathematics based on the Sundanese cultural background, which encompasses the areas of West Java and Banten, because Sundanese language and culture is taught in both regions. The Sundanese culture area, which is based on the Sundanese kingdom, includes the Jakarta area (Sunda Kelapa) and the western part of Central Java. Sundanese is still used in Central Java, bordering West Java, although some West Java residents use Javanese. Moreover, in areas like Cirebon, there is a combination of Javanese and Sundanese cultures, forming unique cultural characteristics. In this study, Sundanese ethnomathematics covers West Java and Banten's regional background, both with the general Sundanese cultural background and the traditional territory.

\subsection{The scope of the Sundanese Ethnomathematics Study}

There were 72 journal articles and proceedings and 43 student research reports that were used to describe the scope of Sundanese ethnomathematics studies. The data used in this section are data that have not gone through the selection process at the eligibility stage. At this stage, it still contained source documents related to Sundanese ethnomathematics studies but not related to Sundanese ethnomathematics as a teaching approach.

Referring to the International Study Group on Ethnomathematics, which describes four areas of general interest in ethnomathematics (Rosa \& Shirley, 2016), in general, two areas of interest are contained in existing document sources, namely: (1) field research, where data on mathematics in culture collected and (2) application of ethnomathematics in the classroom. The following is a breakdown of each area of interest in ethnomathematics based on the type of document.

Table 2. Ethnomathematics areas of interest

\begin{tabular}{lcc}
\hline \multirow{2}{*}{ Types of Document } & \multicolumn{2}{c}{ Number of documents } \\
\cline { 2 - 3 } & Mathematics and culture & Curriculum and Teaching \\
\hline Local Journals & 18 & 29 \\
International Journals & 2 & 5 \\
Scopus-Proceedings & 7 & 7 \\
Undergraduate Theses & 24 & 14 \\
\hline
\end{tabular}




\begin{tabular}{lcc}
\hline \multirow{2}{*}{ Types of Document } & \multicolumn{2}{c}{ Number of documents } \\
\cline { 2 - 3 } & Mathematics and culture & Curriculum and Teaching \\
\hline Master Theses & 2 & 0 \\
Dissertations & 1 & 1 \\
\hline \multicolumn{1}{c}{ Total } & 54 & 56 \\
\hline
\end{tabular}

Based on the source document data in Table 2, it is clear that the number of ethnomathematics studies related to the relationship between mathematics and culture and the application of ethnomathematics in curriculum and teaching is quite balanced even though there are large differences in details. Of the total source documents, only two authors do not have affiliation with universities in West Java and Banten, which have a Sundanese cultural background.

The earliest Sundanese ethnomathematics study was conducted in 2013 in the form of a student thesis research. Then more studies were conducted in the form of research for student theses and dissertations and journal articles and proceedings. The cultural background or area coverage of West Java and Banten is relatively evenly distributed. However, there are several backgrounds for Sundanese indigenous people, such as the Baduy community in Banten, Kampung Naga (Naga village) in Tasikmalaya, Kampung Kuta (Kuta village) in Ciamis, Cirebon culture, and the indigenous Ciptagelar community in Sukabumi. These indigenous peoples' backgrounds are interesting to study to reveal Sundanese ethnomathematics heritage preserved because it is indigenous culture. This section will first present studies of Sundanese ethnomathematics, which links Mathematics and Culture.

What is the scope of mathematics and culture studies? Ethnographic methods carry out almost all research on the relationship between mathematics and culture. Ethnomathematics research using ethnographic methods is mostly based on the Framework for Ethnomathematical Research (Alangui, 2010).

The following are some of the research findings summarized from source documents that are considered presenting studies of the relationship between mathematics and culture, which, according to the authors, provide representative reports and can represent other documents' substances (see Table 3).

Table 3. Findings about Relationship between Mathematics and Sundanese Culture

\begin{tabular}{cl}
\hline \multicolumn{1}{c}{ Authors } & \multicolumn{1}{c}{ Research focuses } \\
\hline Arisetyawan (2015) & $\begin{array}{l}\text { This research conducted on the Baduy community was } \\
\text { focused on exploring various mathematical thinking } \\
\text { processes, which are classified into the seven elements } \\
\text { of the ethnographic framework as universal } \\
\text { anthropological elements of culture including social } \\
\text { elements, language elements, scientific systems, } \\
\text { technology systems, religious systems, livelihood } \\
\text { systems, and art systems. } \\
\text { Research reveals mathematical ideas of geometry and } \\
\text { social arithmetic in the Baduy weaving culture. } \\
\text { Rivaldi (2018) } \\
\text { This research on Salapan village community, Karawang } \\
\text { revealed the origin of the name Salapan (translated into } \\
\text { "sembilan" in Indonesian language or number "nine" in }\end{array}$ \\
\hline
\end{tabular}


Hermanto et al. (2019)

Septianawati et al. (2017)

Umbara et al. (2019)

Suprayo et al. (2019)

Mustika (2013)

Febriyanti et al. (2018)

Pratiwi and Pujiastuti (2020)

Supriadi and Arisetyawan (2020)

Muchyidin (2016)

Mahuda (2020)

Saputra (2017)

Sudirman et al. (2018)

Maharani and Maulidia (2018)
Research focuses

English language) village and elements of social life influenced by the philosophy of number nine.

This research conducted on Naga village community, Tasikmalaya, revealed that the activities of the Naga village community as an indigenous community has mathematical nuances include counting activity, measuring activity, build design activity, and provisions in the making/renovating residential houses

This research on Naga village community was conducted to reveal measurement units, including units of length, units of area, and units of volume.

This research conducted on the traditional community of Cigugur, Kuningan revealed the Palintangan device, which is part of the agricultural system knowledge in the Sundanese cultural structure. Farmers use Palintangan to calculate and determine the right days for plantings, such as Kolenjer (Baduy), Tunuk (Kampung Naga), and Tunduk (Ciwidey Bandung).

This research conducted on Suranenggala Kidul village community, Cirebon revealed an ethnomathematics activity in agricultural activities, including measuring land and measuring the amount of rice. These two activities are related to the concepts of rank and series, concepts of geometry, and concepts of calculus

This research was focused on exploring the values of traditional games and mathematical ideas contained in Kaneker games from the Baduy community.

Research on games for Sundanese people such as Engklek (similar to Hopscotch) and Gasing (similar to wooden spinning top)

Research on marbles game in sundanese context

Research on Endog-endogan game

This research was focused on exploring mathematical ideas in Sundanese batik motifs : Trusmi Cirebon batik

Lebak batik

Kuningan batik

Indramayu batik

This research was focused on exploring mathematical ideas in traditional house architecture, namely, traditional Panjalinan houses 


\begin{tabular}{ll}
\hline \multicolumn{1}{c}{ Authors } & \multicolumn{1}{c}{ Research focuses } \\
\hline $\begin{array}{l}\text { Imswatama and Zultiar } \\
\text { (2019) }\end{array}$ & Resourch on houses in Sukabumi \\
Prabawati (2016) & $\begin{array}{l}\text { Research reveals mathematical ideas on various motifs } \\
\text { of mendong and woven crafts in Tasikmalaya }\end{array}$ \\
Puritea (2018) & Research reveals mathematical ideas on ceramic art \\
\hline
\end{tabular}

Findings can be grouped into the framework of the seven universal elements that form culture, namely, social elements, language elements, scientific systems, technology systems, religious systems, livelihood systems, and art systems (Arisetyawan, 2015). Sundanese ethnomathematics research that focuses on these seven elements can be carried out in an indigenous community that maintains local cultural wisdom from generation to generation and is considered an indigenous community such as the Baduy community in Banten (Arisetyawan, 2015). Similar research with Arisetyawan (2015) can also be carried out, including in Naga village in Tasikmalaya, Kuta village in Ciamis, and Ciptagelar village in Sukabumi which still running indigenous Sundanese culture. Sundanese ethnomathematics research results that reveal the relationship between culture and mathematics can be used as teaching and learning resources in schools or education in general to preserve Sundanese culture. The next discussion will be directed to how ethnomathematics is applied in curriculum and teaching in schools.

\subsection{Sundanese Ethnomathematisc Integration Model in the School Curriculum}

Mathematics has become a part and practice in every culture. Mathematics needs to be integrated into the curriculum in schools. According to the current curriculum model, educators who think critically and creatively can integrate ethnomathematics (Brandt \& Chernoff, 2015). The ethnomathematics approach to the mathematics curriculum aims to make school mathematics more relevant and meaningful for students and to disseminate their knowledge, skills, and attitudes and maintain their cultural identity (Balamurugan, 2015). The authors use five different ethnomathematics curriculum models (Adam, 2004) to explore the integration model of Sundanese ethnomathematics into the school's mathematics curriculum. Based on the results of categorization of 56 documents, it was found that a document tends towards a model even though it has links to other categories.

Table 4. Categorization of documents based on five models of ethnomatematic curriculum integration

\begin{tabular}{lcccccc}
\hline \multicolumn{1}{c}{ Type of Document } & Model 1 & Model 2 & Model 3 & Model 4 & Model 5 & Total \\
\hline Local Journals & 9 & 5 & 5 & 10 & 29 \\
International Journals & 4 & & & 1 & 5 \\
Scopus-Proceedings & & & 2 & 5 & 7 \\
Undergraduate Theses & 7 & & 2 & 5 & 14 \\
Master Theses & 1 & & & & 1 \\
Dissertations & 21 & 5 & 14 & 21 & 56 \\
\hline \multicolumn{1}{c}{ Total } & & & & & \\
\hline
\end{tabular}

Description :

Model 1 : ethnomathematics as a context which is meaningful for the development of thinking skills 
Model 2 : ethnomathematics as a specific cultural content distinct from universal mathematical concepts

Model 3 : ethnomathematics as a stage in the development of mathematical thinking that the child goes through

Model 4 : creating a classroom containing a cultural context in the form of values, beliefs and learning theory

Model 5 : presenting mathematical concepts and practices derived from the culture of students

Table 4 presents data on the results of document categorization that identifies the curriculum integration model being developed. The distribution of categories shows the dominance of model $5(37.5 \%)$ and model 1 (37.5\%), followed by model $4(25 \%)$. Based on the analysis results, all documents tended to describe curriculum development at the level of teaching development in the classroom.. None of them specifically discussed the integration model of Sundanese ethnomathematics at the school curriculum level, because almost everything is related to integration at the curriculum implementation level at the classroom level. Studies related to the Sundanese ethnomathematics integration model at the level of the curriculum framework have not provided comprehensive research results. Based on the categorization in Table 4, the development of Sundanese ethnomathematics-based mathematics teaching was mostly done by exploring the culture of students with a Sundanese cultural background and elements of Sundanese culture in general or in cultural communities, which were then used as teaching materials and resources. Several teaching development models can be referenced from several documents whose studies are sufficient and are considered can represent studies in other documents (see Table 5).

Table 5. Findings about models of ethnomatematic curriculum integration

\begin{tabular}{|c|c|}
\hline Authors & Research focuses \\
\hline (Supriadi, 2014, 2020) & $\begin{array}{l}\text { This development of teaching in an ethnomathematics-based } \\
\text { curriculum was carried out through a sequence of studies on (a) } \\
\text { cultural problems in society, (b) cultural values of the } \\
\text { Sundanese people, and then presenting them in the form of (c) } \\
\text { contextual problems. }\end{array}$ \\
\hline $\begin{array}{l}\text { (Supriadi, 2019; Supriadi } \\
\text { \& Arisetyawan, 2020) }\end{array}$ & $\begin{array}{l}\text { Teaching design referred to a contextual approach. The } \\
\text { ethnomathematics curriculum integration model developed in } \\
\text { this study was relevant to model } 1 \text { and model 5, presenting } \\
\text { ethnomathematics as a meaningful context relevant to the } \\
\text { student's cultural background. Although this research was } \\
\text { conducted on the students of Elementary Teacher Education, } \\
\text { starting from this research, much more research was developed } \\
\text { at the elementary school level. }\end{array}$ \\
\hline $\begin{array}{l}\text { (Arisetyawan, 2019; } \\
\text { Febriyanti et al., 2018; } \\
\text { Supriadi \& Arisetyawan, } \\
\text { 2019; Supriadi et al., } \\
\text { 2016) }\end{array}$ & $\begin{array}{l}\text { This development of teaching in an ethnomathematics-based } \\
\text { curriculum was carried out by developing and using } \\
\text { Mathematics teaching materials, traditional games, and } \\
\text { traditional Sundanese cultural crafts to build a classroom } \\
\text { atmosphere with cultural nuances which is in line with Model } 4\end{array}$ \\
\hline $\begin{array}{l}\text { (Supriadi, Susilawati, et } \\
\text { al., 2019) }\end{array}$ & $\begin{array}{l}\text { This development of teaching in an ethnomathematics-based } \\
\text { curriculum was carried out to facilitate students' mathematical } \\
\text { thinking activities, such as Model } 3 \text {, which can be developed } \\
\text { along with the application of other ethnomathematics } \\
\text { curriculum integration models }\end{array}$ \\
\hline
\end{tabular}




\subsection{Sundanese Ethnomathematisc-Based Mathematics Teaching Approach}

Several possible approaches that can be considered part of the development of ethnomathematics teaching in schools are problem-posing and problem-solving, openended, and realistic mathematics education approach (Peni \& Baba, 2019). In the 56 documents analyzed, there are various approaches, models, or methods used to integrate Sundanese ethnomathematics in mathematics teaching in schools. Most of the research (40 of the 56 documents) used the Experimental Method or Developmental Research Methods, namely, Didactical Design Research (DDR), Define, Design, Develop and Disseminate (4D), and Analysis, Design, Develop, Implement and Evaluate (ADDIE).

In general, there are two classifications for the use of approaches, models, and methods for ethnomathematics-based teaching: (a) the use of specifically defined approaches, models, and methods to facilitate the integration of Sundanese ethnomathematics in mathematics teaching in schools; and (b) the use of non-specifically defined Sundanese ethnomathematics approaches, models, and methods or Sundanese ethnomathematics-based mathematics teaching. The following is a categorization of the approaches, models, and teaching methods used based on the analysis of 56 documents (see Table 6).

Table 6. Categorization of documents based on the sundanese ethnomathematics-based mathematics teaching approaches

\begin{tabular}{lccc}
\hline \multicolumn{1}{c}{ Type of Document } & Model 1 & Model 2 & Total \\
\hline Local Journals & 11 & 18 & 29 \\
International Journals & 1 & 4 & 5 \\
Scopus-Proceedings & 3 & 4 & 7 \\
Undergraduate Theses & 3 & 11 & 14 \\
Master Theses & & & \\
Dissertations & 1 & & 1 \\
\hline \multicolumn{1}{c}{ Total } & 19 & 37 & 56 \\
\hline
\end{tabular}

The results of the categorization showed that there was a tendency to use model 2 (66.07\%) than model 1 (33.93\%) (see Table 6). In model 1, it was shown that there were several teaching approaches, models, or methods that were predominantly used to carry out Sundanese ethnomathematics-based teaching which is presented in Table 7.

Table 7. Teaching approach, models and method used in sundanese ethnomathematics-based teaching

\begin{tabular}{lrl}
\hline \multicolumn{1}{c}{$\begin{array}{c}\text { Teaching Approach, Models } \\
\text { and Method }\end{array}$} & n & \multicolumn{1}{c}{ Authors } \\
\hline $\begin{array}{l}\text { Realistic Mathematics Education } \\
\text { (RME) }\end{array}$ & 5 & $\begin{array}{l}\text { (Ardianingsih et al., 2019; Irawan et al., } \\
\text { 2018; Irawan et al., 2019; Mahpudin \& } \\
\text { Sunanto, 2019; Nugraha \& Suryadi, } \\
\text { 2015) } \\
\text { Problem Based Learning }\end{array}$ \\
& $5 \begin{array}{l}\text { (Anggara, 2019; Fadillah et al., 2019; } \\
\text { Maulana et al., 2020; Perdana \& } \\
\text { Isrokatun, 2019; Tuti, 2018) }\end{array}$ \\
\hline
\end{tabular}




\begin{tabular}{lrl}
\hline \multicolumn{1}{c}{$\begin{array}{c}\text { Teaching Approach, Models } \\
\text { and Method }\end{array}$} & n & \multicolumn{1}{c}{ Authors } \\
\hline Contextual Teaching Learning & 3 & $\begin{array}{l}\text { (Kusuma, 2019b; Nugraha et al., 2020; } \\
\text { Supriadi, 2014) }\end{array}$ \\
$\begin{array}{l}\text { Somatic Approach, Auditory, } \\
\text { Visualization, and Intellectually (SAVI) }\end{array}$ & 2 & $\begin{array}{l}\text { (Farokhah, 2015; Farokhah et al., 2017) } \\
\text { Process Oriented Guided Inquiry }\end{array}$ \\
$\begin{array}{l}\text { Learning (POGIL) } \\
\text { Learning Cycle Approach }\end{array}$ & 1 & (Fakhruddin \& Masrukan, 2018) \\
Guided Invention & 1 & (Sariningsih \& Kadarisma, 2016) \\
Hypnoteaching & 1 & (Permatasari, 2016) \\
\hline Total & 1 & (Kusuma, 2019a) \\
\hline
\end{tabular}

Based on Table 7, Realistic Mathematics Education (RME), Contextual TeachingLeaning and Problem Solving, wich were cosidered very relevant for mathematics teaching design. However, the authors will not specifically discuss this model 1 because it is not the focus of this research, and the Sundanese ethnomathematics teaching design will adjust to the approaches, models, and methods used.

As for model 2, the use and development of ethnomathematics-based teaching did not explicitly show the use of approaches, models, and other methods such as in model 1. In model 2, ethnomathematics teaching design was developed in the form of developing and using teaching material, teaching media, tradisional game, ethnomathematics as teaching approach as presented in Figure 3.

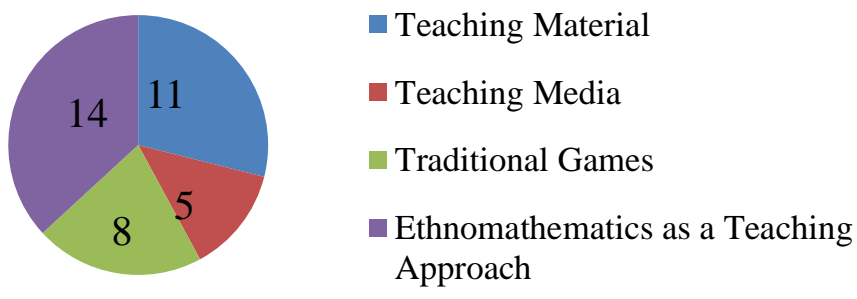

Figure 3. The form of ethnomathematics teaching design

The following is a description of Sundanese ethnomathematics teaching based on the types of teaching components found from document analysis.

\subsubsection{Ethnomathematics teaching materials}

Ethnomathematics teaching materials are teaching materials that are systematically organized using sources derived from local culture and wisdom, which can be in the form of printed materials, audio, video, and multimedia (Arisetyawan, 2019). For example, teaching materials based on the Cirebon people's local culture were a set of mathematics teaching materials packaged using the Cirebon community's local cultural content (Mahpudin \& Yuliati, 2019). Students were introduced to several objects with cultural and mathematical elements in teaching materials, such as unique local Sundanese shapes and objects related to mathematical elements (Imswatama \& Lukman, 2018). The development of teaching materials follows the general stages so that in developing Sundanese ethnomathematics- 
based teaching materials, the teacher must explore and select Sundanese cultural elements that will be used as a context relevant to the mathematical content being studied by students. However, the teaching materials must contain at least three elements, namely: (a) problems related to the Sundanese culture which are related to mathematics; (b) cultural values contained in Sundanese culture; and (c) the design of contextual problems that can be solved by mathematics (Supriadi, Chudari, et al., 2019).

\subsubsection{Media for ethnomathematics teaching}

The use of Media for teaching mathematics is adjusted to teaching needs that are relevant to teaching design and teaching materials such as using traditional Sundanese cultural tools in the classroom even though in the form of artificial models, such as household tools, agricultural tools, clothing materials such as batik, crafts, and art. There are only a few documents that showed the use of Media as a focus in research, but the use of Media as a teaching component was a part of Sundanese ethnomathematics teaching. Some documents were considered emphasizing the use of media, one document related to the use of sticks for learning to count (Citra, 2017), the rest of them showed the use of computer-based technology to help visualize the context of ethnomathematics-based teaching materials (Ferdianto \& Setiyani, 2018; Sudirman et al., 2020).

\subsubsection{Traditional games}

Apart from teaching materials, the use and development of traditional games for ethnomathematics-based teaching were more dominant than the media, mainly due to the need for an attractive and fun teaching approach in schools. Several traditional games had been adopted, such as Engklek (similar to hopscotch) (Rahmawati et al., 2017), Endogendogan (Supriadi \& Arisetyawan, 2019), marbles games (Pratiwi \& Pujiastuti, 2020), and Gasing (similar to wooden spinning top) (Febriyanti et al., 2018). Teaching was designed by including play activities as the main element of learning activities or subsidiary learning activities to build a pleasant atmosphere for students so that they can feel the richness of their culture.

\subsubsection{Ethnomathematics teaching design}

In model 1, the development of ethnomathematics teaching design refers to specific approaches, models, and methods used, such as following the principles and designs of teaching RME, PBL, and CTL. While in model 2, the teaching design is designed to adjust to the general design of teaching development and is relevant to teaching materials, media, and types of traditional games used. The following is a model of the stages of ethnomathematics teaching that is quite clearly presented (Supriadi, Chudari, et al., 2019), relevant to the ethnomathematics curriculum unit framework in Figure 1 (Adam, 2004). From all the documents analyzed, the rest of them had not developed an original model. On the contrary, they applied a teaching approach, model, and method or developing teaching based on the current national curriculum guidelines by integrating teaching materials, media, and traditional games. It is challenging to conduct research and development of Sundanese ethnomathematics teaching designs that are compatible with the Indonesian national curriculum model and become one of the curriculum innovations that can be applied in schools.

Based on the analysis of 56 documents, it was indicated that the implementation of Sundanese ethnomathematics based teaching was mostly carried out at the elementary (32 documents) and junior high school (14 documents) levels and rarely at the senior high school level ( 2 documents) and early childhood level (1 document). Some teaching activities were 
conducted on mathematics students and students of the Department of Primary School Teacher Education and Mathematics Education (7 documents).

\subsection{Mathematics Learning Objectives with Sundanese Ethnomathematics Approach}

D'Ambrosio introduces the Trivium Mathematics Curriculum as a concept that combines literacy, matheracy, and technocracy to place mathematics in a sociocultural context that is relevant to students (Rosa \& Orey, 2015). Trivium Mathematics Curriculum recommends a pedagogical activity related to problem-solving, modeling, critical assessment, and understanding mathematical ideas, procedures, and practices from students' sociocultural environment (Rosa \& Orey, 2015). In addition to those activities, which can be used as ethnomathematics learning objectives, the objectives of learning mathematics for all levels of education also include mastery of content standards including numbers, geometry, and measurement as well as data processing and process standards including mathematical understanding, mathematical problem solving, mathematical connections, and mathematical representation mathematical communication skills (Joyner \& Reys, 2000). In another version, it is stated that mathematics learning objectives are called mathematical proficiency, which includes conceptual understanding, procedural fluency, strategic competence, adaptive reasoning, and productive disposition (Kilpatrick, 2001). Learning objectives can also refer to a taxonomy of learning outcomes such as Bloom's taxonomy, or various abilities that are relevant to mathematics learning objectives.

The following shows some of the competencies and mathematics learning outcomes that are the onjectives of learning mathematics. The data presented may not be by the number of articles because a study may contain more than one competency variable and mathematics learning outcome. Therefore, the data is presented cumulatively and not based on document categories.

Table 8. Categorization of documents based on mathematics learning objectives

\begin{tabular}{lc}
\hline \multicolumn{1}{c}{ Mathematics Learning Objectives } & $\begin{array}{c}\text { Total/ } \\
\text { variabel }\end{array}$ \\
\hline Creative thinking & 10 \\
General learning outcomes; mathematical understanding; problem-solving & 9 \\
Mathematical disposition & 6 \\
(Ethno)mathematical literacy; mathematical modeling & 4 \\
Geometrical thinking; critical thinking; mathematical communication & 3 \\
Algebraic thinking; student participation; mathematical connection; respect to & 2 \\
cultural values & \\
Mathematical abstraction; mathematical thinking; metaphorical thinking; cognitive & 1 \\
style; reflective thinking; mathematical generalization; HOTS; self-regulated & \\
learning; motivation; mathematical reasoning; resiliency & \\
\hline
\end{tabular}

Table 8 shows that 25 mathematical competencies are the objectives of ethnomathematics-based teaching, which were found om 56 documents; among the five competencies were the affective domains (mathematical disposition, independent learning, respect for cultural values, motivation, and resilience). The general learning outcomes in question were that the documents did not mention a specific competency but mentioned the mathematics learning outcomes based on general competencies.

Three salient competencies that appear in the sources as competencies developed through ethnomathematics learning are creative thinking (10), problem-solving (9), and mathematical understanding (9). It shows that ethnomathematics-based mathematics- 
teaching has relevance to mathematics learning objectives, especially to develop students' thinking skills.

\section{CONCLUSION}

The studies of Sundanese ethnomathematics and its integration into mathematics teaching in schools in Indonesia, based on the search results, only started in 2011, while ethnomathematics studies as a field of study began in 1984. This study shows that Sundanese ethnomathematics studies are still developing by adopting various thinking frameworks developed in other countries or other communities. Ethnomathematics studies in Indonesia continue to develop and show the uniqueness that other countries do not have because Indonesia is a country with various cultures, ethnicities, and languages, which have the potential for various ethnomathematics studies. Ethnomathematics studies and their application in teaching in schools are expected to help students appreciate, preserve, and develop their cultural wealth. The study of ethnomathematics can be broadly divided into two, namely, the study of mathematics and culture and integrating ethnomathematics into the curriculum and teaching in schools. Through the study of mathematics and culture, we can explore cultural wealth relevant to mathematics as a cultural heritage reflected in the seven cultural elements including social elements, language elements, scientific systems, technology systems, religious systems, livelihood systems, and art systems. Meanwhile, curriculum and teaching development that integrates ethnomathematics can be used as an alternative in order to create more contextual mathematics teaching-learning that is close to student culture so that it can build the ability of various mathematical thinking and mathematical literacy and foster appreciation for the wealthy local wisdom of Sundanese culture and diverse Indonesian cultures.

This systematic literature review research has presented the development of research on Sundanese ethnomathematics both on the relationship of mathematics and culture as well as the integration of Sundanese ethnomathematics in the curriculum in learning. This research will serve as a reference for future research on this topic. The studies that have been carried out have not shown a complete model of the integration of Sundanese ethnomathematics into the school curriculum. Even so, alternative approaches and learning models can continue to be developed. Although RME, PBL and CTL can be a strong foundation for teaching Sundanese ethnomathematics, it is necessary to develop an approach and model that is more relevant to the character of students and the curriculum model that applies in Indonesia.

\section{REFERENCES}

Abdullah, A. S. (2017). Ethnomathematics in perspective of sundanese culture. Journal on Mathematics Education, 8(1), 1-16.

Adam, S. (2004). Ethnomathematical ideas in the curriculum. Mathematics Education Research Journal, 16(2), 49-68. https://doi.org/10.1007/BF03217395

Alangui, W. V. (2010). Stone walls and water flows: Interrogating cultural practice and mathematics. Doctoral dissertation. University of Auckland Auckland, New Zealand. Retrieved from http://hdl.handle.net/2292/5732

Anggara, B. (2019). Desain pembelajaran matematika pada konsep dasar peluang berbasis kearifan lokal Indramayu [Design of mathematics learning on the basic concept of 
opportunity based on local wisdom of Indramayu]. JNPM (Jurnal Nasional Pendidikan Matematika), 3(2), 223-237. https://doi.org/10.33603/jnpm.v3i2.2377

Ardianingsih, A., Lusiyana, D., \& Rahmatudin, J. (2019). Penerapan pembelajaran realistic mathematic education berbasis etnomatematika untuk meningkatkan HOTs matematik siswa [Application of realistic mathematics education based on ethnomathematics to improve students' mathematical HOTs]. Mathline : Jurnal Matematika dan Pendidikan Matematika, 4(2). https://doi.org/10.31943/mathline.v4i2.117

Arisetyawan, A. (2015). Etnomatematika masyarakat Baduy. Doctoral dissertation. Universitas Pendidikan Indonesia. Retrieved from http://repository.upi.edu/19410/

Arisetyawan, A. (2019). Pentingnya pembelajaran Etnomatematika dalam meningkatkan kemampuan kognitif siswa dan bagaimana mendisain bahan ajar berbasis kearifan lokal [The importance of ethnomathematics learning in improving students' cognitive abilities and how to design teaching materials based on local wisdom]. Jurnal Basicedu, 3(2), 621-626. https://doi.org/10.31004/basicedu.v3i2.47

Balamurugan, M. (2015). Ethnomathematics; an approach for learning mathematics from multicultural perspectives. International journal of modern research and reviews, 3(6), 716-720.

Borba, M. C. (1990). Ethnomathematics and Education. For the learning of Mathematics, 10(1), 39-43. http://www.jstor.org/stable/40247974

Brandt, A., \& Chernoff, E. J. (2015). The importance of ethnomathematics in the math class. Ohio Journal of School Mathematics, Fall 2014(71), 31-36. Retrieved from https://kb.osu.edu/bitstream/handle/1811/78917/OJSM_71_Spring2015_31.pdf

Cimen, O. A. (2014). Discussing ethnomathematics: Is mathematics culturally dependent? Procedia - Social and Behavioral Sciences, 152, 523-528. https://doi.org/10.1016/j.sbspro.2014.09.215

Citra, R. J. (2017). Pengaruh media lidimatika dalam pembelajaran etnomatematika sunda untuk mengembangkan kemampuan pemecahan masalah matematis pada operasi perkalian siswa sekolah dasar. Thesis. Universitas Pendidikan Indonesia.

D'Ambrosio, U. (1985). Ethnomathematics and its place in the history and pedagogy of mathematics. For the learning of Mathematics, 5(1), 44-48. Retrieved from http://www.jstor.org/stable/40247876

D'Ambrosio, U. (2001). General remarks on ethnomathematics. Zdm, 33(3), 67-69. https://doi.org/10.1007/BF02655696

Eglash, R. (2000). Anthropological Perspectives on Ethnomathematics. In H. Selin (Ed.), Mathematics Across Cultures: The History of Non-Western Mathematics (pp. 13-22). Springer Netherlands. https://doi.org/10.1007/978-94-011-4301-1_2

Fadillah, L., Subroto, T., \& Praja, E. S. (2019). Kemampuan komunikasi matematis dan respons siswa pada model problem based learning berbasis etnomatematika [Mathematical communication ability and student responses on ethnomathematicsbased problem-based learning models]. Jurnal Edukasi dan Sains Matematika (JESMAT), 5(1), 71-81. https://doi.org/10.25134/jes-mat.v5i1.1722 
Fakhruddin, D. F., \& Masrukan, M. (2018). The analysis of mathematical literacy skill and respect to local culture toward pogil learning with ethnomathematics. Unnes Journal of Mathematics Education Research, 7(1), 145-151.

Farokhah, L. (2015). Pengaruh pendekatan SAVI berbasis etnomatematika terhadap kemampuan komunikasi matematis dalam konsep bangun ruang di kelas V SDN Serang 11. Thesis. Universitas Pendidikan Indonesia. Retrieved from http://repository.upi.edu/19505/

Farokhah, L., Arisetyawan, A., \& Jupri, A. (2017). The effect of ethnomathematics-based SAVI (somatic, auditory, visualization, intelectually) approach on mathematical communication skill on geometry in elementary school. International E-journal of Advances in Education, 3(9), 534-543. https://doi.org/10.18768/ijaedu.370417

Febriyanti, C., Prasetya, R., \& Irawan, A. (2018). Etnomatematika pada permainan tradisional engklek dan gasing khas kebudayaan sunda [Ethnomathematics in traditional engklek and gasing games typical of Sundanese culture]. Barekeng: Jurnal Ilmu Matematika Dan Terapan, 12(1), 1-6. https://doi.org/10.30598/vol12iss1pp1-6ar358

Ferdianto, F., \& Setiyani, S. (2018). Pengembangan bahan ajar media pembelajaran berbasis kearifan lokal mahasiswa pendidikan matematika [Development of teaching materials for learning media based on local wisdom for mathematics education students]. JNPM (Jurnal Nasional Pendidikan Matematika), 2(1), 37-47. https://doi.org/10.33603/jnpm.v2i1.781

François, K. (2010). The role of ethnomathematics within mathematics education. In Proceedings of CERME.

Gay, G. (2000). Culturally responsive teaching: Theory, practice and research.

Hermanto, R., Wahyudin, \& Nurlaelah, E. (2019). Exploration of ethnomathematics on the kampung naga indigenous peoples. Journal of Physics: Conference Series, 1315(1), 012072. https://doi.org/10.1088/1742-6596/1315/1/012072

Imswatama, A., \& Lukman, H. S. (2018). The effectiveness of mathematics teaching material based on ethnomathematics. International Journal of Trends in Mathematics Education Research, 1(1), 35-38.

Imswatama, A., \& Zultiar, I. (2019). Etnomatematika: Arsitektur rumah adat di Sukabumi sebagai bahan pembelajaran matematika di pendidikan dasar [Ethnomathematics: Traditional house architecture in Sukabumi as materials for learning mathematics in elementary education]. ARITHMETIC: Academic Journal of Math, 1(2), 119-130. https://doi.org/10.29240/ja.v1i2.1007

Irawan, A., Kencanawaty, G., \& Febriyanti, C. (2018). Realistic mathematics and ethnomathematics in improving problem solving abilities. Journal of Physics: Conference Series, 1114, 012108. https://doi.org/10.1088/1742$6596 / 1114 / 1 / 012108$

Irawan, A., Lina, I. M., Adnyani, L. P. W., Pinahayu, E. A. R., Alamsyah, N., Sulistyaniningsih, E., Hatmoko, B. D., \& Rangka, I. B. (2019). Designing of realistic mathematics learning based on ethnomathematics and plane figure. Journal of Physics: Conference Series, 1175, 012050. https://doi.org/10.1088/17426596/1175/1/012050 
Joyner, J., \& Reys, B. (2000). Principles and Standards for School Mathematics: What's in It for You? Teaching Children Mathematics TCM, 7(1), 26-29. https://doi.org/10.5951/tcm.7.1.0026

Kilpatrick, J. (2001). Where's the evidence? Journal for Research in Mathematics Education, 32(4), 421-427. https://doi.org/10.2307/749702

Kusuma, D. A. (2019a). Penerapan ethnomathematics dan hypnoteaching pada mata kuliah matematika kimia [Application of ethnomathematics and hypnoteaching in mathematics chemistry courses]. JNPM (Jurnal Nasional Pendidikan Matematika), 3(2), 165-176. https://doi.org/10.33603/jnpm.v3i2.2279

Kusuma, D. A. (2019b). Peningkatan komunikasi matematis siswa menggunakan pembelajaran kontekstual berbasis etnomatematika dengan penerapan mozart effect (studi eksperimen terhadap siswa sekolah menengah pertama) [Improving students' mathematical communication using ethnomathematical-based contextual learning with the application of the Mozart effect (experimental study of junior high school students)]. Teorema: Teori dan Riset Matematika, 4(1), 65-74. https://doi.org/10.25157/teorema.v4i1.1954

Maharani, A., \& Maulidia, S. (2018). Etnomatematika dalam rumah adat Panjalin [Ethnomathematics in the Panjalin traditional house]. Wacana Akademika, 2(2), 224235. https://doi.org/10.30738/wa.v2i2.3183

Mahpudin, M., \& Sunanto, L. (2019). Ethnomathematics an alternative in the development of multicultural education at the primary school. Social, Humanities, and Educational Studies (SHEs): Conference Series, 1(2), 269-273. https://doi.org/10.20961/shes.v1i2.26872

Mahpudin, M., \& Yuliati, Y. (2019). Pengembangan bahan ajar matematika berbasis budaya lokal masyarakat Cirebon [Development of mathematics teaching materials based on local culture of the Cirebon people]. Jurnal Sekolah Dasar, 4(2), 50-56. https://doi.org/10.36805/jurnalsekolahdasar.v4i2.883

Mahuda, I. (2020). Eksplorasi etnomatematika pada motif batik lebak dilihat dari sisi nilai filosofi dan konsep matematis [Ethnomathematical exploration of the Lebak batik motif in terms of philosophical values and mathematical concepts]. Jurnal Lebesgue : Jurnal Ilmiah Pendidikan Matematika, Matematika dan Statistika, 1(1), 29-38. https://doi.org/10.46306/lb.v1i1.10

Maksimova, E. (1967). A Dialogue. Soviet Education, 9(5), 16-20. https://doi.org/10.2753/RES1060-9393090516

Maulana, G., Zaenuri, Z., \& Junaedi, I. (2020). Pattern of problem solving skill reviewed based on student cognitive style after experienced problem based learning model with ethnomathematics nuances. Journal of Primary Education, 9(2), 209-219.

Moher, D., Liberati, A., Tetzlaff, J., Altman, D. G., \& The, P. G. (2009). Preferred reporting items for systematic reviews and meta-analyses: The PRISMA statement. PLOS Medicine, 6(7), e1000097. https://doi.org/10.1371/journal.pmed.1000097

Muchyidin, A. (2016). Model matematika kearifan lokal masyarakat desa trusmi dalam menjaga eksistensi kerajinan batik tulis [Mathematical model of local wisdom of the Trusmi village community in maintaining the existence of hand-drawn batik]. Jurnal Edukasi dan Sains Matematika (JES-MAT), 2(1), 12-25. https://doi.org/10.25134/jes-mat.v2i1.268 
Mustika, R. G. (2013). Study ethnomathematics pada permainan Keneker masyarakat adat Baduy. Thesis. Universitas Pendidikan Indonesia. Retrieved from http://repository.upi.edu/1970/

Na'im, A., \& Syaputra, H. (2010). Hasil sensus penduduk 2010: Kewarganegaraan, suku bangsa, agama, dan bahasa sehari-hari penduduk Indonesia [The results of the 2010 population census: Citizenship, ethnicity, religion, and everyday language of the Indonesian population]. Badan Pusat Statistik.

Nam, N. D., Thao, T. T. P., \& Bannavong, O. (2018). An ethnomathematical approach in mathematics education: A case study of Vietnamese secondary schools. In Proceedings of the International Conference on Teachers and Educational Administrators' Competence in the Context of Globalisatio,(April). Thai Nguyen, Vietnam.

Nugraha, E., \& Suryadi, D. (2015). Peningkatan kemampuan berfikir matematis siswa SD kelas III melalui pembelajaran matematika realistik berbasis permainan tradisional [Improving the mathematical thinking ability of third grade elementary school students through realistic mathematics learning based on traditional games]. EduHumanioral Jurnal Pendidikan Dasar Kampus Cibiru, 7(1). https://doi.org/10.17509/eh.v7i1.2794

Nugraha, T., Maulana, M., \& Mutiasih, P. (2020). Sundanese Ethnomathematics Context in Primary School Learning. 2020, 7(1), 13. https://doi.org/10.17509/mimbarsd.v7i1.22452

Orey, D. C., \& Rosa, M. (2006). Ethnomathematics: Cultural assertions and challenges towards pedagogical action. The journal of Mathematics and Culture, 1(1), 57-78.

Peni, N. R. N., \& Baba, T. (2019). Consideration of curriculum approaches of employing ethnomathematics in mathematics classroom. Journal of Physics: Conference Series, 1321(3), 032125. https://doi.org/10.1088/1742-6596/1321/3/032125

Perdana, D. C., \& Isrokatun, I. (2019). Problem-based learning and ethnomathematics on mathematical understanding. Journal of Physics: Conference Series, 1318(1), 012134. https://doi.org/10.1088/1742-6596/1318/1/012134

Permatasari, R. (2016). Pengembangan bahan ajar materi himpunan melalui penemuan terbimbing berbasis etnomatematika pada pembelajaran di SMP. Thesis. Universitas Pendidikan Indonesia. Retrieved from http://repository.upi.edu/27394/

Prabawati, M. N. (2016). Etnomatematika masyarakat pengrajin anyaman Rajapolah kabupaten Tasikmalaya [Ethnomathematics of the Rajapolah woven craftsman community, Tasikmalaya district]. Infinity, 5(1), 25-31. https://doi.org/10.22460/infinity.v5i1.p25-31

Pratiwi, J. W., \& Pujiastuti, H. (2020). Eksplorasi etnomatematika pada permainan tradisional Kelereng [Ethnomathematical exploration of the traditional game of Marbles]. 2020, 5(2), https://ejournal.unib.ac.id/index.php/jpmr/article/view/11405

Puritea, V. F. (2018). Seni keramik Purwakarta dalam perspektif etnomatematika. Thesis. Universitas Pendidikan Indonesia. Retrieved from http://repository.upi.edu/37568/

Rahmawati, N. D., Buchori, A., \& Bhihikmah, B. (2017). Pengembangan strategi permainan tradisional Sunda Manda pada pembelajaran matematika di SMP [Development of 
Sunda Manda traditional game strategy in mathematics learning in junior high school]. 2017, 1(2), 165-172. https://doi.org/10.26877/jipmat.v1i2.1243

Ricardo, J., \& Mafra, S. (2020). Desafiando o currículo tradicional por conhecimentos tradicionais: do trabalho de campo etnomatemático às práticas em sala de aula [Challenging the traditional curriculum by traditional knowledges: from ethnomathematical fieldwork to classroom practices]. Revemop, 2, e202006e202006. https://doi.org/10.33532/revemop.e202006

Ridwan, M. (2018). Etnomatematika: Tinjauan aspek geometris tenun suku Baduy di desa Kanekes kabupaten Lebak provinsi Banten. Thesis. Universitas Pendidikan Indonesia. Retrieved from http://repository.upi.edu/36618/

Rivaldi, M. r. (2018). Studi etnomatematika masyarakat kampung salapan kabupaten Karawang. Thesis. Universitas Pendidikan Indonesia.

Rosa, M., \& Orey, D. C. (2015). A trivium curriculum for mathematics based on literacy, matheracy, and technoracy: an ethnomathematics perspective. Zdm, 47(4), 587-598. https://doi.org/10.1007/s11858-015-0688-1

Rosa, M., \& Orey, D. C. (2016). State of the Art in Ethnomathematics. In M. Rosa, U. D’Ambrosio, D. C. Orey, L. Shirley, W. V. Alangui, P. Palhares, \& M. E. Gavarrete (Eds.), Current and Future Perspectives of Ethnomathematics as a Program (pp. 1137). Springer International Publishing. https://doi.org/10.1007/978-3-319-301204_3

Rosa, M., \& Shirley, L. (2016). Introduction. In Current and Future Perspectives of Ethnomathematics as a Program (pp. 1-3). Springer International Publishing. https://doi.org/10.1007/978-3-319-30120-4_1

Rowlands, S., \& Carson, R. (2002). Where would formal, academic mathematics stand in a curriculum informed by ethnomathematics? A critical review of ethnomathematics. Educational Studies in Mathematics, 50(1), 79-102. https://doi.org/10.1023/A:1020532926983

Saputra, D. H. (2017). Study ethnomathematics: Pengungkapan aspek-aspek matematika pada aktivitas membatik di rumah produksi Nisya Batik desa Cikubangsari kabupaten Kuningan Jawa Barat. Thesis. Universitas Pendidikan Indonesia. Retrieved from http://repository.upi.edu/32886/

Sariningsih, R., \& Kadarisma, G. (2016). Meningkatkan kemampuan berpikir kreatif matematis dan kemandirian belajar siswa SMP melalui pendekatan saintifik berbasis etnomatematika [Improving mathematical creative thinking skills and learning independence of junior high school students through a scientific approach based on ethnomathematics]. Jurnal Ilmiah P2M STKIP Siliwangi, 3(1), 53-56. https://doi.org/10.22460/p2m.v3i1p53-56.478

Septianawati, T., Turmudi, \& Puspita, E. (2017). Ethnomathematics study: uncovering units of length, area, and volume in Kampung Naga Society. Journal of Physics: Conference Series, 812, 012021. https://doi.org/10.1088/1742-6596/812/1/012021

Sudirman, S., Son, A. L., \& Rosyadi, R. (2018). Penggunaan etnomatematika pada Batik Paoman dalam pembelajaran geomteri bidang di sekolah dasar [The use of ethnomathematics in Batik Paoman in learning geometry in elementary schools]. IndoMath: Indonesia Mathematics Education, 1(1), 27-34. https://doi.org/10.30738/indomath.v1i1.2093 
Sudirman, S., Yaniawati, R. P., Melawaty, M., \& Indrawan, R. (2020). Integrating ethnomathematics into augmented reality technology: exploration, design, and implementation in geometry learning. Journal of Physics: Conference Series, 1521(3), 032006. https://doi.org/10.1088/1742-6596/1521/3/032006

Suprayo, T., Noto, M. S., \& Subroto, T. (2019). Ethnomathematics exploration on units and calculus within a village farmer community. Journal of Physics: Conference Series, 1188, 012104. https://doi.org/10.1088/1742-6596/1188/1/012104

Supriadi, S. (2014). Mengembangkan kemampuan dan disposisi pemodelan serta berpikir kreatif matematik mahasiswa PGSD melalui pembelajaran kontekstual berbasis etnomatematika. Thesis. Universitas Pendidikan Indonesia.

Supriadi, S. (2019). Didactic design of sundanese ethnomathematics learning for primary school students. International Journal of Learning, Teaching and Educational Research, 18(11), 154-175. https://doi.org/10.26803/ijlter.18.11.9

Supriadi, S. (2020). Pre-service elementary teachers: analysis of the disposition of mathematical modeling in ethno mathematics learning. Ilkogretim Online, 19(3), 1407-1421. https://doi.org/10.17051/ilkonline.2020.730747

Supriadi, S., \& Arisetyawan, A. (2019). Pembelajaran etnomatematika Sunda melalui permainan Endog-endogan dan Engklek untuk siswa sekolah dasar dalam materi pecahan. In Prosiding SI MaNIs (Seminar Nasional Integrasi Matematika dan NilaiNilai Islami).

Supriadi, S., \& Arisetyawan, A. (2020). Didactical design of Sundanese ethnomathematics learning with Endog-endogan and Engklek games in primary school. Journal of Physics: Conference Series, 1567(2), 022087. https://doi.org/10.1088/17426596/1567/2/022087

Supriadi, S., Arisetyawan, A., \& Tiurlina, T. (2016). Mengintegrasikan pembelajaran matematika berbasis budaya Banten pada pendirian SD laboratorium UPI kampus Serang [Integrating Banten culture-based mathematics learning in the establishment of the UPI Laboratory Elementary School, Serang campus]. 2016, 3(1), 1-18. https://doi.org/10.53400/mimbar-sd.v3i1.2510

Supriadi, S., Chudari, I. N., Sundari, N., Tiurlina, I. R., Wuryastuti, S., Alfarisa, F., \& Robiansyah, F. (2019). Creative intelligence analysis in ethnomathematics learning. International Journal of Innovation, Creativity and Change, 5(1), 169-188.

Supriadi, S., Susilawati, S., \& Tristyanto, B. (2019). Ethnomathematics in mathematics, social and physical education. Journal of Physics: Conference Series, 1318(1), 012126. https://doi.org/10.1088/1742-6596/1318/1/012126

Tuti, H. (2018). Model problem based learning (PBL) berbasis ethnomathematics untuk meningkatkan kemampuan literasi matematis. Thesis. Universitas Pendidikan Indonesia. Retrieved from http://repository.upi.edu/32594/

Umbara, U., Wahyudin, W., \& Prabawanto, S. (2019). Ethnomatematics : how does cigugur traditional community use palintangan on farming. Journal of Physics: Conference Series, 1265(1), 012025. https://doi.org/10.1088/1742-6596/1265/1/012025 